\title{
Asymptomatic Bacteriuria among Women Attending the Antenatal Clinics in Jeddah, Western Region of Saudi Arabia
}

\author{
Hanan M. Ali Shamrani, ABOG \\ Department of Obstetrics and Gynecology \\ Faculty of Medicine, King Abdulaziz University \\ Jeddah, Saudi Arabia
}

\section{Correspondence}

Dr. Hanan M. Shamrani

P.O. Box P.O. Box 80215, Jeddah 21589

e.M: halshmrani@kau.edu.sa

Submission: 18 Jan. 2016

Accepted: 15 Mar. 2016

\section{Citation}

Shamrani HM. Asymptomatic Bacteriuria among Women Attending the Antenatal Clinics in Jeddah, Western Region of Saudi Arabia. JKAU Med Sci 2016; 23 (2): 39-47. DOI: 10.4197/ Med. 23.2 .5

\begin{abstract}
This retrospective chart review was conducted to determine the proportion of pregnant women with asymptomatic bacteriuria who were followed up at the antenatal clinics of King Abdulaziz University Hospital, Jeddah between January 2007 and January 2012. Clinical and paraclinical data were recorded for 337 women in their last trimester of pregnancy. The prevalence of asymptomatic bacteriuria in the cohort was $31.26 \%$. The most frequently isolated bacteria included Escherichia coli and Klebsiella pneumoniae in $30.39 \%$ and $10.78 \%$ of the cases, respectively. In most cases, the isolated bacteria were sensitive to ampicillin (11.57\%), amoxicillin (10.38\%), and amikacin (5.63\%). Most bacteria were resistant to nitrofurantoin (21.06\%), tetracycline (21.06\%) and cefixime (20.77\%). The most common prescribed medications included multivitamins $(n=40 ; 11.87 \%)$, vitamin $B 12(n=47 ; 13.95 \%)$, folic acid $(n=45 ; 13.35 \%)$, and antibiotics ( $n=43 ; 12.75 \%)$. Overall, it is possible that pregnant women with asymptomatic bacteriuria are undertreated at our institution. Gaps in the management of these patients should be identified to improve patient care.
\end{abstract}

\section{Keywords}

Antibiotherapy; Asymptomatic bacteriuria; Pregnancy; Third trimester

\section{Introduction}

symptomatic bacteriuria (ASB) is the presence of pathogenic bacteria in the urine at clinically significant levels (> 100,000 colony forming units / $\mathrm{mL}$ of urine) in the absence of symptoms suggestive of urinary tract infection ${ }^{[1]}$. The reported prevalence of ASB ranges between 2 and $10 \%$ among pregnant women ${ }^{[2]}$. Although the prevalence is not higher in pregnant women, pregnancy augments the progression rate from asymptomatic to symptomatic disease ${ }^{[3]}$. During pregnancy, certain factors favor the multiplication of bacteria in urine $e^{[4]}$. These include weakening of the immune system, which occurs as a result of physiological changes ${ }^{[5]}$, increased plasma volume due to a decrease in urine concentration and the development of glycosuria in approximately $70 \%$ of pregnant women ${ }^{[6]}$. Other factors, such as poor socioeconomic status, gestational age, pregnancy duration, and multiparity have been associated with an increase in the incidence of asymptomatic bacteriuria ${ }^{[7,8]}$. According to a previous report, advanced 
maternal age might increase the risk for asymptomatic bacteriuria in pregnancy ${ }^{[7]}$; however, women $\geq 35$ years are likely to have had several pregnancies, and multiparity itself increases the risk of asymptomatic bacteriuria ${ }^{[7]}$. Poor genital hygiene is another risk factor that might promote bacterial infection and/or increase chances of bacterial colonization and, consequently, contribute to asymptomatic bacteriuria ${ }^{[9]}$.

A 2002 systematic review concluded that (a) the diagnosis of urinary tract infection can be confirmed with a $>90 \%$ probability in a patient who presents a combination of dysuria and frequency in the absence of vaginal discharge or irritation and (b) a urine dipstick test cannot decrease the post-test probability sufficiently to exclude urinary tract infection if a patient has $\geq 1$ symptoms ${ }^{[10]}$. Nevertheless, urine culture has a value beyond confirming the diagnosis as it can additionally help clinicians direct treatment based on the results of tests for antimicrobial susceptibility.

Previous reports found that, in up to $40 \%$ of the cases, ASB can progress to pyelonephritis, and the risk of pre-eclampsia, premature birth and low birth weight are presumably increased ${ }^{[11-16]}$. It has been demonstrated that it can be more cost effective to screen for ASB in pregnant women than treating women with UTI or pyelonephritis ${ }^{[17]}$. The American College of Obstetrics and Gynecology advocates routine screening for bacteriuria with a urine culture at the first antenatal consultation and during the third trimester ${ }^{[18]}$. The US Preventive Services Task Force recommends screening for bacteriuria with urine culture at 12-16 weeks of gestation in order to identify $80 \%$ of women who will subsequently develop $\operatorname{ASB}^{[19]}$.

Antibiotic treatment is rarely indicated in ASB; however, it is recommended in pregnant women ${ }^{[20]}$. The choice of antibiotic depends on several criteria, including the patient's individual risk (allergy to an antibiotic agent), previous antibiotic treatment, pathogen spectrum and results of tests for antimicrobial susceptibility, efficacy of the antibiotic, effects on the resistance situation in the patient, as well as the presence of undesired drug effects ${ }^{[21]}$. A Cochrane Review of treatments for ASB during pregnancy reported that based on the results of susceptibility testing, a cephalosporin, sulfonamide or sulfonamide-containing combination, penicillin, or nitrofurantoin were appropriate regimens for the management of $\mathrm{ASB}^{[22]}$. Nevertheless, an increase in the rates of antibiotic resistance complicates the choice of empiric regimens. In addition, antibiotic resistance is likely to become an increasing issue. Few surveys of antibiotic resistance in urinary isolates from women with ASB have been conducted, but findings from surveys of antibiotic susceptibility in pathogens that cause community-acquired uncomplicated urinary tract infections indicate substantial variability ${ }^{[22]}$. In one survey of European countries and Canada ${ }^{[23]}$, investigators found that resistance to ampicillin in Escherichia coli was on average $29.8 \%$ but was as high as $53.9 \%$ in Spain.

There is a dearth of more recent data on ASB, including its screening and management, among pregnant women in Jeddah. It is important to identify the prevalence of ASB among our patients and to determine whether patients are managed according to current recommendations in order to limit complications and poor pregnancy outcomes. This study determines the proportion of women with ASB who were treated at the antenatal clinics of King Abdulaziz University Hospital (KAUH), Jeddah.

\section{Methods}

A retrospective chart review was conducted of pregnant women who were followed up at the antenatal clinics of KAUH, Jeddah between January 2007 and January 2012. King Abdulaziz University Hospital is a tertiary center, which has a capacity of 104 beds for academic specialties only. Approximately 1500 pregnant women are received every month at the antenatal clinics of the hospital.

A total of 337 women in the last trimester of pregnancy were included, after excluding pregnant women in the first and second trimesters as well as pregnant women with non-urologic infections. Permission to conduct the study was sought from the relevant ethics research committee.

A data collection sheet was used to record demographic and clinical data from the electronic medical records of included cases. According to our departmental protocol, routine urine microscopy was performed during each antenatal visit. A urine culture was also performed (midstream urine sample) during the third trimester or when urine microscopy results were suggestive of bacteriuria. Patients who had a positive culture were offered antibiotic therapy tailored to sensitivity results. After the course of antibiotics was completed, urine culture was repeated in the next antenatal visit for follow up. 


\section{Statistical Methods}

The data were entered and analyzed using IBM SPSS Statistics for Windows, version 22 (IBM Corp., Armonk, NY, USA). Descriptive statistics were used to define the characteristics of the study variables. Results are expressed as proportions and means (standard deviation [SD]).

\section{Results}

The mean (SD) age of the cohort was 29.87 (4.80) years (range, 15 and 46 years). The mean gravidity was 3.05 (1.60) and the mean parity was 21.96 (1.40). Other characteristics are as shown in Table 1.

As shown in Table 2, the range of medications prescribed during pregnancy was broad, with the most commonly prescribed being calcium $(n=106 ; 31.45 \%)$, followed by multivitamins ( $n=40 ; 11.87 \%$ ), vitamin B12 ( $n=47 ; 13.95 \%)$, folic acid $(n=45 ; 13.35 \%)$, and antibiotics ( $n=43 ; 12.75 \%)$. Urinary tract symptoms were reported by a very small proportion of the women, with the most common being burning sensation on micturition (3.56\%) and dysuria (3.26\%). Urgency was reported in less than one percent of the women (Table $3)$.

Urinary tract infection was documented in ten women $(n=10 ; 2.96 \%)$. Approximately $19.58 \%$ of the women had leukocytosis, while $2.67 \%$ of the cases had a positive urine nitrite test (Table 4). Bacteria were isolated from the urine of 102 women, representing

Table 1. Characteristics of the sample.

\begin{tabular}{|c|c|}
\hline \multicolumn{1}{|c|}{ Variables } & Frequency (Percent)* \\
\hline Age (years) & $84(24.93 \%)$ \\
\hline$<20$ & $134(39.76 \%)$ \\
\hline $20-34$ & $101(29.97 \%)$ \\
\hline $35-45$ & $18(5.34 \%)$ \\
\hline$>45$ & $265(81.29 \%)$ \\
\hline Nationality & $61(18.41 \%)$ \\
\hline Saudi & $1(0.87 \%)$ \\
\hline Non-Saudi & $114(99.13 \%)$ \\
\hline Occupation & $155(41.11 \%)$ \\
\hline Employed & $114(33.82 \%)$ \\
\hline Unemployed & $68(20.17 \%)$ \\
\hline Gravidity & $17(5.15 \%)$ \\
\hline G1 & $313(94.65 \%)$ \\
\hline G2-G5 & \\
\hline$>$ G5 & \\
\hline Diabetes & \\
\hline Yes & \\
\hline No & \\
\hline *The total is < 337 due to missing data. &
\end{tabular}

a prevalence rate of $31.26 \%$. Of these, Escherichia coli (E. coli) and Klebsiella pneumoniae (K. pneumoniae) were isolated from the urine of $30.39 \%$ and $10.78 \%$ of the cases, respectively. The relative frequency of other isolated bacteria was as follows: beta-hemolytic streptococci (2.94\%), Gram-negative bacilli (1.96\%), mixed bacteria growth (1.96\%), Enterococcus faecalis (1.96\%), Gram-negative Klebsiella (0.98\%), Grampositive cocci (0.98\%), Gram-negative bacilli (1.96\%), and Proteus species (0.98\%). A summary of the prevalence rates and frequency of ASB due to E. coli across different geographic locations is presented in Table 5.

Table 6 shows that in most cases, the isolated bacteria were sensitive to ampicillin (11.57\%), amoxicillin (10.38\%), and amikacin (5.63\%). Most bacteria were resistant to nitrofurantoin (21.06\%), tetracycline (21.06\%) and cefixime (20.77\%).

Table 2. Frequency of medications taken by the women during pregnancy.

\begin{tabular}{|l|c|}
\hline \multicolumn{1}{|c|}{ Variables } & Frequency (Percent) \\
\hline Antibiotics & $43(12.75 \%)$ \\
\hline Albuterol Sulfate Inhalation for asthma & $1(0.30 \%)$ \\
\hline Cefuroxime & $1(0.30 \%)$ \\
\hline Vitamin D & $15(4.45 \%)$ \\
\hline Folic acid & $45(13.35 \%)$ \\
\hline Vitamin B12 & $47(13.95 \%)$ \\
\hline Multivitamin & $40(11.87 \%)$ \\
\hline Calcium & $106(31.45 \%)$ \\
\hline Omega-3 Polyunsaturated Fatty Acids & $4(1.18 \%)$ \\
\hline Dexamethasone & $1(0.30 \%)$ \\
\hline Dydrogesterone & $5(1.48 \%)$ \\
\hline Ranitidine & $2(0.59 \%)$ \\
\hline Dexpanthenol Cream & $1(0.30 \%)$ \\
\hline Cefazolin & $1(0.30 \%)$ \\
\hline Calcium Carbonate & $1(0.30 \%)$ \\
\hline Lactulose & $1(0.30 \%)$ \\
\hline Ferrous Sulfate & $11(3.26 \%)$ \\
\hline Bath Salts & $1(0.30 \%)$ \\
\hline Pantoprazole & $1(0.30 \%)$ \\
\hline Folic Acid Injection & $1(0.30 \%)$ \\
\hline Meclizine & $1(0.30 \%)$ \\
\hline Domperidone & $1(0.30 \%)$ \\
\hline
\end{tabular}

Table 3. Frequency of urogenital tract symptoms.

\begin{tabular}{|l|c|}
\hline \multicolumn{1}{|c|}{ Variables } & Frequency (Percent) \\
\hline Dysuria & $11(3.26 \%)$ \\
\hline Frequency & $8(2.37 \%)$ \\
\hline Burning Sensation on Micturition & $12(3.56 \%)$ \\
\hline Urgency & $1(0.30 \%)$ \\
\hline Vaginal Discharge & $24(7.12 \%)$ \\
\hline
\end{tabular}


Table 4. Proportion of positive findings on urine analysis, cytology and culture.

\begin{tabular}{|l|c|}
\hline \multicolumn{1}{|c|}{ Variables } & Frequency (Percent) \\
\hline Hematuria & $3(0.89 \%)$ \\
\hline Leukocytes & $66(19.58 \%)$ \\
\hline Proteinuria & $11(3.26 \%)$ \\
\hline Nitrites & $9(2.67 \%)$ \\
\hline Glucose & $12(3.56 \%)$ \\
\hline Epithelial cells & \\
\hline Few & $134(39.76 \%)$ \\
\hline Moderate & $35(10.38 \%)$ \\
\hline Klebsiella pneumoniae & $11(10.78 \%)$ \\
\hline Gram-positive Cocci & $1(0.98 \%)$ \\
\hline Beta-hemolytic Streptococci & $3(2.94 \%)$ \\
\hline Gram-negative Klebsiella & $1(0.98 \%)$ \\
\hline Gram-positive Cocci & $1(0.98 \%)$ \\
\hline Gram-negative Bacilli & $2(1.96 \%)$ \\
\hline Escherichia coli & $31(30.39 \%)$ \\
\hline Mixed Bacteria Growth & $2(1.96 \%)$ \\
\hline Enterococcus faecalis & $2(1.96 \%)$ \\
\hline Proteus Species & $1(0.98 \%)$ \\
\hline
\end{tabular}

\section{Discussion}

This analysis shows that the prevalence of ASB among pregnant women in the third trimester is $31.26 \%$. The prevalence of ASB in this cohort is low compared with the rate reported by Yousef and Al-Aali ${ }^{[24]}$, who found that the prevalence of ASB was $62 \%$ among women attending the antenatal clinic at Al-Hada Armed Forces Hospital, Taif, Saudi Arabia. These results are converse of those reported by other authors ${ }^{[25-27]}$, with one study reporting that the prevalence of ASB was 5.1\% among pregnant women who were followed up at the antenatal clinics of Hafez Hospital, Shiraz, Iran ${ }^{[27]}$. In another study conducted at Buea District Hospital, Cameroon ${ }^{[25]}$, it was found that the prevalence rate of ASB among pregnant women was $23.5 \%$.

A Cochrane review recommended that treatment schedules for ASB in pregnant women should be directed by urine culture and sensitivity testing ${ }^{[28]}$. In the current study, although bacteria were isolated from the urine of approximately $31.26 \%$ of the cohort and sensitivity testing was done for all cases with bacteriuria, only $12.75 \%$ of the women received antibiotics. This finding suggests the possibility that departmental protocols are not followed or are

Table 5. Summary of prevalence rates and frequency of asymptomatic bacteriuria due to E. coli in studies conducted both in Saudi Arabia and abroad.

\begin{tabular}{|c|c|c|}
\hline Study Sample and Location & Prevalence (\%) & E. coli $(\%)$ \\
\hline \multicolumn{3}{|l|}{ Gulf Region } \\
\hline $\begin{array}{l}\text { Current study: Women in the last trimester of pregnancy attending antenatal clinics at King Abdulaziz University, Jeddah, Jeddah } \\
\text { Province }\end{array}$ & $31.26 \%$ & $30.39 \%$ \\
\hline $\begin{array}{l}\text { Women attending their first antenatal clinic at King Abdulaziz University Hospital and Dr. Erfan and Bagedo Hospital, Jeddah, } \\
\text { Western Province }\end{array}$ & $1.7 \%$ & $53.0 \%$ \\
\hline Pregnant Saudi women visiting the antenatal clinics of a university hospital in Al-Khobar ${ }^{[4]]}$ & $10.5 \%$ & Not reported \\
\hline Pregnant women visiting the antenatal clinics of a maternity hospital in Yemen ${ }^{[42]}$ & $30.0 \%$ & $41.5 \%$ \\
\hline Women attending antenatal clinics at primary health care centers in Qatar ${ }^{[43]}$ & $9.9 \%$ & $31.0 \%$ \\
\hline Women visiting the antenatal clinics of public health centers in Semnan, $\operatorname{Iran}^{[44]}$ & $3.3 \%$ & $70.0 \%$ \\
\hline Women attending antenatal clinics at the Primary Health Care Center of Maternal Child Health in Sharjah, United Arab Emirates ${ }^{[45]}$ & $4.8 \%$ & $66.7 \%$ \\
\hline \multicolumn{3}{|l|}{ Asia } \\
\hline $\begin{array}{l}\text { Pregnant women attending the Department of Obstetrics and Gynecology at Raja Isteri Pengiran Anak Saleha Hospital in Brunei } \\
\text { Darussalam }{ }^{[46]}\end{array}$ & $4.1 \%$ & $1.18 \%$ \\
\hline Pregnant women who reside in Bahawalpur, Pakistan ${ }^{[4]]}$ & $9.9 \%$ & $78.6 \%$ \\
\hline Women in the second trimester of pregnancy living in the rural areas of Rajshahi District, Bangladesh ${ }^{[48]}$ & $12.0 \%$ & $75.9 \%$ \\
\hline $\begin{array}{l}\text { Women attending their first antenatal clinic at the Department of Obstetrics and Gynecology of Universiti Kebangsaan Malaysia, } \\
\text { Malaysia }{ }^{[49]}\end{array}$ & $1.9 \%$ & $40.0 \%$ \\
\hline \multicolumn{3}{|l|}{ Africa } \\
\hline Women attending antenatal clinics at Komfo Anokye Teaching Hospital in Ghana ${ }^{[50]}$ & $7.3 \%$ & $37.0 \%$ \\
\hline Women attending antenatal clinics at the Federal Teaching Hospital in Abakaliki, Nigeria ${ }^{[51]}$ & $24.7 \%$ & $28.4 \%$ \\
\hline Women followed up at the antenatal clinics of Buea Regional Hospital Annex and health centers at Mile 16 in Buea, Cameroon ${ }^{[25]}$ & $23.5 \%$ & $33.0 \%$ \\
\hline \multicolumn{3}{|l|}{$\begin{array}{cc} & \text { Europe } \\
\end{array}$} \\
\hline $\begin{array}{l}\text { Women aged } \geq 18 \text { years with a singleton pregnancy (gestational age, } 16 \text { and } 22 \text { weeks) attending antenatal clinics at eight } \\
\text { hospitals and five ultrasound centers in the Netherlands }{ }^{[52]}\end{array}$ & $5.0 \%$ & $71.0 \%$ \\
\hline
\end{tabular}


Table 6. Frequency and antimicrobial susceptibility of the isolated bacteria.

\begin{tabular}{|c|c|c|}
\hline Antibiotic & & Frequency (Percentage) \\
\hline \multirow[t]{2}{*}{ Amikacin } & Yes & $19(5.63 \%)$ \\
\hline & No & $55(16.32 \%)$ \\
\hline \multirow[t]{2}{*}{ Cefixime } & Yes & $2(0.59 \%)$ \\
\hline & No & $70(20.77 \%)$ \\
\hline \multirow[t]{2}{*}{ Nitrofurantoin } & Yes & $1(0.30 \%)$ \\
\hline & No & $71(21.06 \%)$ \\
\hline \multirow[t]{2}{*}{ Tetracycline } & Yes & $1(0.30 \%)$ \\
\hline & No & $71(21.06 \%)$ \\
\hline \multirow[t]{2}{*}{ 0xacillin } & Yes & $4(1.86 \%)$ \\
\hline & No & $69(20.47 \%)$ \\
\hline \multirow[t]{2}{*}{ Ciprofloxacin } & Yes & $14(4.15 \%)$ \\
\hline & No & $58(17.21 \%)$ \\
\hline \multirow[t]{2}{*}{ Ampicillin } & Yes & $39(11.57 \%)$ \\
\hline & No & $32(9.49 \%)$ \\
\hline \multirow[t]{2}{*}{ Amoxicillin } & Yes & $35(10.38 \%)$ \\
\hline & No & $39(11.57 \%)$ \\
\hline \multirow[t]{2}{*}{ Moxifloxacin } & Yes & $6(1.78 \%)$ \\
\hline & No & $66(19.58 \%)$ \\
\hline \multirow[t]{2}{*}{ Levofloxacin } & Yes & $3(0.89 \%)$ \\
\hline & No & $69(20.47 \%)$ \\
\hline \multirow[t]{2}{*}{ Cephalexin } & Yes & $6(1.78 \%)$ \\
\hline & No & $67(19.88 \%)$ \\
\hline \multirow[t]{2}{*}{ Cefotaxime } & Yes & $3(0.89 \%)$ \\
\hline & No & $67(19.88 \%)$ \\
\hline \multirow[t]{2}{*}{ Levofloxacin } & Yes & $14(4.15 \%)$ \\
\hline & No & $56(16.61 \%)$ \\
\hline \multirow[t]{2}{*}{ Clindamycin } & Yes & $1(0.30 \%)$ \\
\hline & No & $69(20.47 \%)$ \\
\hline \multirow[t]{2}{*}{ Erythromycin } & Yes & $2(0.59 \%)$ \\
\hline & No & $68(20.17 \%)$ \\
\hline \multirow[t]{2}{*}{ Fosfomycin } & Yes & $2(0.59 \%)$ \\
\hline & No & $68(20.17 \%)$ \\
\hline \multirow[t]{2}{*}{ Gentamycin } & Yes & $2(0.59 \%)$ \\
\hline & No & $68(20.17 \%)$ \\
\hline \multirow[t]{2}{*}{ Cefazolin } & Yes & $1(0.30 \%)$ \\
\hline & No & $69(20.47 \%)$ \\
\hline \multirow[t]{2}{*}{ Imipenem } & Yes & $5(1.48 \%)$ \\
\hline & No & $65(19.28 \%)$ \\
\hline \multirow[t]{2}{*}{ Tigecycline } & Yes & $1(0.30 \%)$ \\
\hline & No & $69(20.47 \%)$ \\
\hline \multirow[t]{2}{*}{ Ciprofloxacin } & Yes & $3(0.89 \%)$ \\
\hline & No & $67(19.88 \%)$ \\
\hline \multirow[t]{2}{*}{ Meropenem } & Yes & $8(2.37 \%)$ \\
\hline & No & 62 (18.39\%) \\
\hline \multirow[t]{2}{*}{ Other Penicillins } & Yes & $15(4.45 \%)$ \\
\hline & No & $57(16.91 \%)$ \\
\hline Other Cephalosporins & Yes & $3(0.89 \%)$ \\
\hline & No & $72(21.36 \%)$ \\
\hline
\end{tabular}

selectively implemented by physicians. Nevertheless, further studies should be conducted at our academic center to investigate the reasons behind the nonprescription of antibiotics to pregnant women with ASB.

The most frequently isolated bacteria in this study were E. coli (30.39\%) and K. pneumoniae $(10.78 \%)$. According to recent reports ${ }^{[29-35]}$, E. coli is the most common uropathogen in pregnant women, representing at least $80 \%$ of isolates ${ }^{[22]}$. Other organisms that are commonly isolated in the urine samples of pregnant women with ASB include other gram negative bacteria and group B streptococci. In one retrospective study conducted on 9698 pregnant women at King Abdulaziz University Hospital and a private clinic at Dr. Erfan and Bagedo Hospital, Jeddah ${ }^{[17]}$, E. coli was isolated from urine specimens in up to $53 \%$ of the sample. Contrary to our report, where K. pneumoniae was identified in $10.78 \%$ of the cases, the authors found Klebsiella species in $0.6 \%$ of the women in their sample. In another study conducted in a tertiary care teaching hospital in north India ${ }^{[36]}$, the authors identified $E$. coli and K. pneumoniae in $60.0 \%$ and $22.5 \%$ of pregnant women, respectively.

In this study, we found that the isolated bacteria were most sensitive to amoxicillin, ampicillin, and amikacin. While antibiotic susceptibility patterns vary between populations or hospitals, several authors found that gentamicin, amikacin and nitrofurantoin were effective against most isolates ${ }^{[33,35,36]}$. Gentamicin and amikacin have been demonstrated to be effective in treating ASB in pregnant women; however, these drugs should only be used when the benefit outweighs potential risk, as they are nephrotoxic ${ }^{[37]}$. Some investigators ${ }^{[22]}$ recommend the use of a sulfonamide or sulfonamide-containing combination, a penicillin, cephalosporin or nitrofurantoin, based on the results of susceptibility testing as appropriate regimens for the management of ASB. Nevertheless, increasing antibiotic resistance complicates the choice of empiric regimens, and is it likely to become an increasing issue, not only among other Gulf countries, but also in Saudi Arabia $^{[38]}$.

In the current study, bacterial isolates were in most cases resistant to nitrofurantoin $(21.06 \%)$, tetracycline (21.06\%) and cefixime (20.77\%). Results from hospitalbased studies conducted in Saudi Arabia showed that resistance rates among isolates of $K$. pneumoniae and E. coli to ciprofloxacin were $23 \%$ and $46 \%$, respectively ${ }^{[39,40]}$. Studies that investigated antibiotic 
resistance in urinary isolates from women with ASB in Saudi Arabia showed varying results ${ }^{[17,38]}$, with some investigators reporting that all the strains identified in their study were susceptible to all tested antibiotics, and resistance to ampicillin was only observed in some strains of $K$. pneumoniae. The emergence of antimicrobial resistance in Saudi Arabia and other Gulf countries might have occurred for several reasons, including easy access to broad spectrum antibiotics, such as third and fourth generation cephalosporins, quinolones and carbapenems in hospitals and clinics ${ }^{[38]}$. Most Gulf countries do not have antimicrobial stewardship programs, especially in the inpatient setting where broad spectrum antimicrobial agents are administered. In addition, many hospitals allow 2 or more bedded rooms. Consequently, there is poor isolation of infected and colonized patients with multidrug resistant organisms. The lack of strong infection control programs, trained infectious disease specialists and clinical pharmacists in the field of infectious diseases has also been reported as one of the factors associated with increased antibiotic resistance. We did not, however, investigate the factors associated with increased antibiotic resistance in this study, as it was not one of our objectives.

This study has all the limitations inherent to retrospective studies, including increased susceptibility to bias in data selection and analysis. Although the findings of this study might indicate whether physicians at our institution are currently following the recommended guidelines to treat pregnant women with ASB, we cannot draw relevant conclusions from this analysis.

\section{Conclusion}

A very small proportion of pregnant women with ASB are treated, indicating possible gaps in the management of these patients, who are at risk of developing a more severe infection. We believe that these findings may be used to identify gaps in management and consequently improve patient care. We therefore recommend that future studies should incorporate items such as the qualification of the treating physician as well as patient- and hospitalrelated characteristics in the design. In referral centers such as KAUH, programs can be integrated to allow for the restricted use of antimicrobial agents and to provide decision-assisted physician order so as to control the use of antibiotics.

\section{Conflict of Interest}

The author has no conflict of interest.

\section{Disclosure}

The author did not receive any type of commercial support either in forms of compensation or financial for this study. The author has no financial interest in any of the products or devices, or drugs mentioned in this article.

\section{Ethical Approval}

Obtained.

\section{References}

[1] Cormican M, Murphy AW, Vellinga A. Interpreting asymptomatic bacteriuria Practice Rational Testing. BMJ 2011; 343: d4780.

[2] Schnarr J, Smaill F. Asymptomatic bacteriuria and symptomatic urinary tract infections in pregnancy. Eur J Clin Invest 2008; 38 Suppl 2: 50-57.

[3] Connolly A, Thorp JM Jr. Urinary Tract Infection in pregnancy. Urol Clin North Am 1999; 26(4): 779-787.

[4] Patterson TF, Andriole VT. Bacteriuria in pregnancy. Infect Dis Clin North Am 1987; 1(4): 807-822.

[5] Lucas MJ, Cunningham FG. Urinary tract infections in pregnancy. Clin Obstet Gynecol 1993; 36(4): 855-868.

[6] Scott EM, McGarrigle HH, Lachelin GC. The increase in plasma and salivary cortisol levels in pregnancy is not due to the increase in corticosteroid binding globulin levels. J Clin Endocrinol Metab 1990; 71(3): 639-644.

[7] Andabati G, Byamugisha J. Microbial aetiology and sensitivity of asymptomatic bacteriuria among ante-natal mothers in Mulago hospital, Uganda. Afr Health Sci 2010; 10(4): 349-352.

[8] Oladeinde BH, Omoregie R, Oladeinde OB. Asymptomatic urinary tract infection among pregnant women receiving ante-natal care in a traditional birth home in Benin City, Nigeria. Ethiop J Health Sci. 2015; 25(1): 3-8.

[9] Akinloye O, Ogbolu DO, Akinloye OM, Terry Alli OA. Asymptomatic bacteriuria of pregnancy in Ibadan, Nigeria: a re-assessment. Br J Biomed Sci 2006; 63(3): 109-112.

[10] Imade PE, Izekor PE, Eghafona NO, Enabulele OI, Ofori E. Asymptomatic bacteriuria among pregnant women. North Am J Med Sci 2010; 2(6): 263-266.

[11] Bent S, Nallamothu BK, Simel DL, Fihn SD, Saint S. Does this woman have an acute uncomplicated urinary tract infection? JAMA 2002; 287: 2701-2710. 
[12] Farkash E, Wientraub AY, Sergienko R, Wiznitzer A, Zlotnik A, Sheiner E. Acute antepartum pyelonephritis in pregnancy: a critical analysis of risk factors and outcomes. Eur J Obstet Gynecol Reprod Biol 2012; 162(1): 24-27.

[13] Gravett CA, Gravett MG, Martin ET, Bernson JD, Khan S, Boyle DS, Lannon SM, Patterson J, Rubens CE, Steele MS. Serious and life-threatening pregnancy-related infections: opportunities to reduce the global burden. Plos Med 2012; 9(10): e1001324.

[14] Foxman B. Epidemiology of urinary tract infections: incidence, morbidity, and economic costs. Dis Med 2003; 49(2): 5-13.

[15] Mazor-Dray E, Levy A, Schlaeffer F, Sheiner E. Maternal urinary tract infection: is it independently associated with adverse pregnancy outcome? J Matern Fetal Neonatal Med 2009; 22(2): 124-132.

[16] Bolton M, Horvath DJ Jr, Li B, Cortado H, Newsom D, White P, Partida-Sanchez S, Justice SS. Intrauterine growth restriction is a direct consequence of localized maternal uropathogenic Escherichia coli cystitis. PLoS One 2012; 7(3): e33897.

[17] Al Sibiani AS. Asymptomatic bacteriuria in pregnant women in Jeddah, Western region of Saudi Arabia: Call for Assessment. J KAU Med Sci 2010; 17(1): 29-42.

[18] [No authors listed]. ACOG educational bulletin. Antimicrobial therapy for obstetric patients. Number 245, March 1998 (replaces no. 117, June 1988). American College of Obstetricians and Gynecologists. Int J Gynaecol Obstet 1998; 61(3): 299-308.

[19] US Preventive Services Task Force. The Guide to Clinical Preventive Services 2007: Recommendations of the U.S. Preventive Services Task Force. Rockville (MD): Agency for Healthcare Research and Quality (US); 2007 Infectious Diseases. Available from: <https://www.ncbi.nlm.nih.gov/ books/NBK16349>

[20] Nicolle LE, Bradley S, Colgan R, Rice JC, Schaeffer A, Hooton TM, Infectious Diseases Society of America, American Society of Nephrology, American Geriatric Society. Infectious Diseases Society of America guidelines for the diagnosis and treatment of asymptomatic bacteriuria in adults. Clin Infect Dis 2005; 40(5): 643-654.

[21] Wagenlehner FM, Hoyme U, Kaase M, Fünfstück R, Naber KG, Schmiemann G. Uncomplicated urinary tract infections. Dtsch Arztebl Int 2011; 108(24): 415-423.

[22] Smaill FM, Vazquez JC. Antibiotics for asymptomatic bacteriuria in pregnancy. Cochrane Database Syst Rev 2015; (8): CD000490.

[23] Al-Aali KY, Yousef W. Prevalence of Asymptomatic Bacteriuria in Pregnant Women, Westren Region, Taif, Saudi Arabia. Int J Sci Research 2015; 4(12): 1125-1131.

[24] Kahlmeter G. ECO.SENS. An international survey of the antimicrobial susceptibility of pathogens from uncomplicated urinary tract infections: the ECO.SENS Project. J Antimicrob Chemother 2003; 51(1): 69-76.
[25] Mokube MN, Atashili J, Halle-Ekane GE, Ikomey GM, Ndumbe PM. Bacteriuria amongst pregnant women in the Buea Health District, Cameroon: prevalence, predictors, antibiotic susceptibility patterns and diagnosis. PLoS One 2013; 8(8): e71086.

[26] Selimuzzaman ABM, Ullah MA, Haque MJ. Asymptomatic bacteriuria during pregnancy: causative agents and their sensitivity in Rajshahi city. TAJ: J Teachers Assoc 2006; 19(2): 66-69.

[27] Kasraeian M, Asadi N, Ghaffarpasand F. Prevalence of asymptomatic bacteriuria among pregnant women in Shiraz, Iran. Saudi Med J 2009; 30(7): 917-920.

[28] Smaill F. Antibiotics for asymptomatic bacteriuria in pregnancy. Cochrane Database Syst Rev 2001; (2): CD000490

[29] Enayat K, Fariba F, Bahram N. Asymptomatic bacteriuria among pregnant women referred to outpatient clinics in Sanandaj, Iran. Int Braz J Urol 2008; 34(6): 699-707.

[30] Imade PE, Izekor PE, Eghafona NO, Enabulele OI, Ophori E. Asymptomatic bacteriuria among pregnant women. N Am J Med Sci 2010; 2(6): 263-266.

[31] Obirikorang C, Quaye L, Bio FY, Amidu N, Acheampong I, Addo K. Asymptomatic bacteriuria among pregnant women attending antenatal clinic at the university hospital, Kumasi, Ghana. J Med Biomed Sci 2012; 1(1): 38-44.

[32] Chandel R, Kanga A, Thakur K, Mokta KK, Sood A, Chauhan $\mathrm{S}$. Prevalence of pregnancy associated asymptomatic bacteriuria: A study done in a tertiary care hospital. J Obstet Gynaecol India 2012; 62(5): 511-5114.

[33] Jain J, Das V, Agarwal A, Pandey A. Asymptomatic bacteriuria and obstetric outcome following treatment in early versus late pregnancy in north Indian women. Indian J Med Res 2013; 137(4): 753-758.

[34] Senthinath TJ, Rajalaksmi PC, Keerthana R, Vigneshwari RS, Revathi RS, Prabhu N, Susethira AR. Prevalence of asymptomatic bacteriuria among antenatal women in rural tertiary care hospital, Tamilnadu, India. Int J Curr Microbiol App Sci 2013; 2(1): 80-85.

[35] Sujatha R, Nawani M. Prevalence of asymptomatic bacteriuria and its antibacterial susceptibility pattern among pregnant women attending the antenatal clinic at Kanpur, India. J Clin Diagn Res 2014; 8(4): DC01-3.

[36] Titoria A, Gupta A, Rathore AM, Prakash SK, Rawat D, Manaktala U. Asymptomatic bacteriuria in women attending an antenatal clinic at a tertiary care centre. S Afr J OG 2014; 20(1): 4-7.

[37] Grayson ML, Whitby M. Nitrofurans: nitrofurazone, furazolidone, and nitrofurantoin. In: KUCERS' The Use of Antibiotics. Vol. 1. Grayson ML, Crowe SM, McCarthy JS, et al., editors. 6th ed. London, England: ASM P, 2010. 11951204

[38] Aly M, Balkhy HH. The prevalence of antimicrobial resistance in clinical isolates from Gulf Corporation Council countries. Antimicrob Resist Infect Control. 2012; 1(1): 26. 
[39] Al-Tawfiq JA, Antony A. Antimicrobial resistance of Klebsiella pneumoniae in a Saudi Arabian hospital: results of a 6-year surveillance study, 1998-2003. J Infect Chemother 2007; 13(4): 230-234.

[40] Al-Tawfiq JA. Increasing antibiotic resistance among isolates of Escherichia coli recovered from inpatients and outpatients in a Saudi Arabian hospital. Infect Control Hosp Epidemiol 2006; 27(7): 748-53.

[41] al-Sibai MH, Saha A, Rasheed P. Socio-biological correlates of bacteriuria in Saudi pregnant women. Public Health 1989; 103(2): 113-121.

[42] Al-Haddad AM. Urinary tract infection among pregnant women in Al-Mukalla district, Yemen. East Mediterr Health J 2005; $11(3)$ : 505-510.

[43] Al-Kuwari MG, Aseel MT, Al-Meer FM, Ismail MF. Prevalence and predictors of asymptomatic bacteriuria among pregnant women attending primary health care in Qatar. Middle East J Fam Med 2009; 7(4): 10-13.

[44] Moghadas AJ, Irajian G. Asymptomatic urinary tract infection in pregnant women. Iran J Pathol 2009; 4(3): 105108.

[45] Abdullah AA, Al-Moslih MI. Prevalence of asymptomatic bacteriuria in pregnant women in Sharjah, United Arab Emirates. East Mediterr Health J 2005; 11(5-6): 1045-1052.

[46] Muharram SH, Ghazali SN, Yaakub HR, Abiola O. A preliminary assessment of asymptomatic bacteriuria of pregnancy in Brunei Darussalam. Malays J Med Sci 2014; 21(2): 34-39.

[47] Fatima N, Ishrat S. Frequency and risk factors of asymptomatic bacteriuria during pregnancy. J Coll Physicians Surg Pak 2006; 16(4): 273-275.

[48] Ullah MA, Barman A, Siddique MA, Haque AK. Prevalence of asymptomatic bacteriuria and its consequences in pregnancy in a rural community of Bangladesh. Bangladesh Med Res Counc Bull 2007; 33(2): 60-64.

[49] Mohammad M, Mahdy ZA, Omar J, Maan N, Jamil MA. Laboratory aspects of asymptomatic bacteriuria in pregnancy. Southeast Asian J Trop Med Public Health 2002; 33(3): 575-580.

[50] Turpin C, Minkah B, Danso K, Frimpong E. Asymptomatic bacteriuria in pregnant women attending antenatal clinic at Komfo Anokye Teaching Hospital, Kumasi, Ghana. Ghana Med J 2007; 41(1): 26-29.

[51] Onu FA, Ajah LO, Ezeonu PO, Umeora OU, Ibekwe PC, Ajah MI. Profile and microbiological isolates of asymptomatic bacteriuria among pregnant women in Abakaliki, Nigeria. Infect Drug Resist 2015; 8: 231-235.

[52] Kazemier BM, Koningstein FN, Schneeberger C, Ott A, Bossuyt PM, de Miranda E, Vogelvang TE, Verhoeven $C J$, Langenveld J, Woiski M, Oudijk MA, van der Ven JE, Vlegels MT, Kuiper PN, Feiertag N, Pajkrt E, de Groot CJ, Mol BW, Geerlings SE. Maternal and neonatal consequences of treated and untreated asymptomatic bacteriuria in pregnancy: a prospective cohort study with an embedded randomised controlled trial. Lancet Infect Dis 2015; 15(11): 1324-1333. 


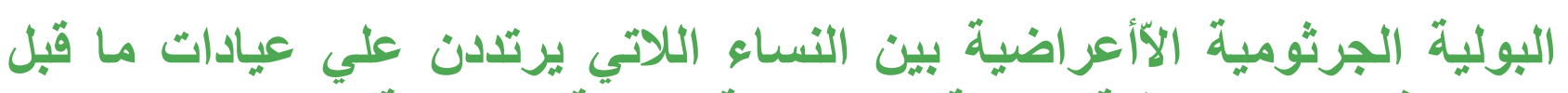 الولادة في جدة بالمنطقة الغربية من المبية بين المملكة العربية السعودية يردية}

\section{حنان محمد علي شمراني \\ قسم النساء والو لادة، كلية الطب، جامعة الملك عبدالعزيز، جدة ـ المعلكة العربية السعودية}

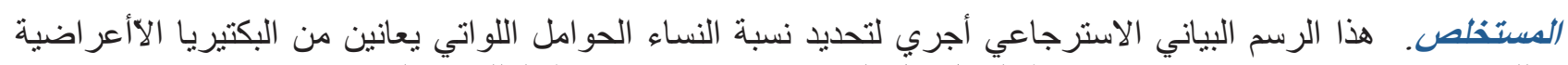

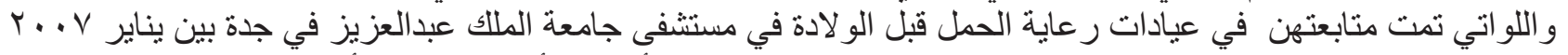

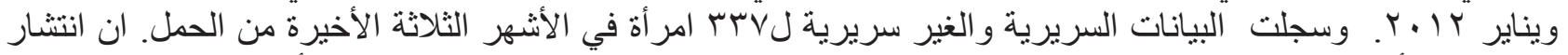

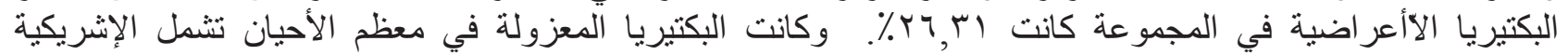

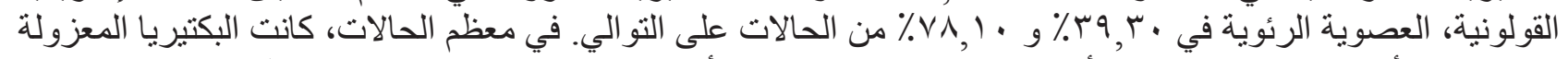

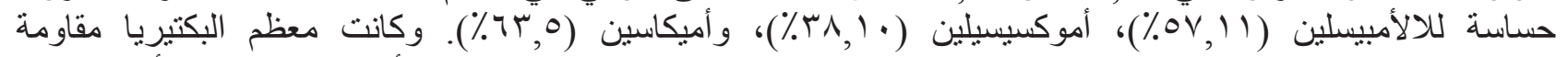

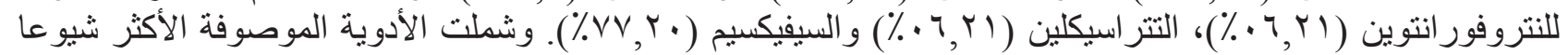

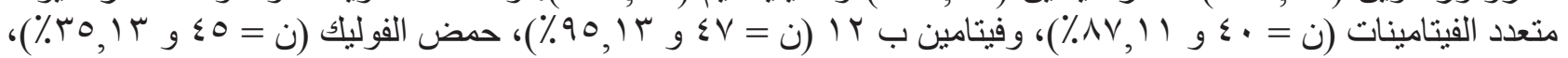

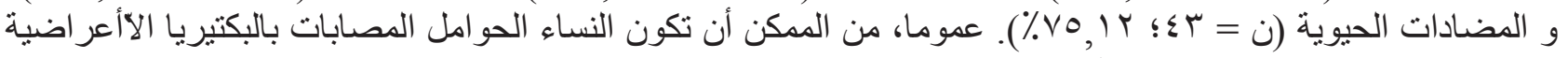

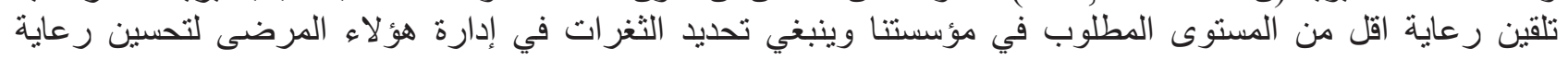

